\title{
KESIAPAN KAWASAN COMMERCIAL STRIP SURAKARTA UTARA BAGIAN BARAT SEBAGAI PUSAT AKTIVITAS BARU
}

\author{
Muhammad Rizal Fernandita Pamungkas', Soedwiwahjono1, Nur Miladan1 \\ ${ }^{1}$ Program Studi Perencanaan Wilayah dan Kota Fakultas Teknik Universitas Sebelas Maret
}

\begin{abstract}
Abstrak
Berdasarkan RTRW Kota Surakarta tahun 2011-2031, Kawasan Surakarta Utara adalah kawasan strategis dari segi pertumbuhan ekonomi. Koridor komersial (commercial strip) di Surakarta Utara bagian Barat direncanakan melalui koridor Jalan Adi Sumarmo, Mangunsarkoro dan Pierre Tendean. Commercial strip adalah pengembangan linear pertokoan dan jasa di sepanjang jalan utama yang melebar hingga satu blok (Silberberg, 1976). Pengembangan pada kawasan Utara diperlukan untuk mengurangi beban aktivitas yang saat ini menjadi pusat aktivitas. Namun, pengembangan pada kawasan Utara masih perlu perbaikan pada aspek fisik dan non-fisik seperti perbaikan infrastruktur penunjang dan tingkat investasi. Dengan begitu, perlu mengetahui bagaimana kesiapan kawasan commercial strip Surakarta Utara bagian Barat dari aspek fisik dan non fisik. Pendekatan penelitian ini adalah deduktif. Metode pengumpumlan data menggunakan teknik purposive sampling, observasi, dan kuesioner pada data primer sedangkan studi literatur pada data sekunder. Teknik analisis menggunakan teknik statistik deskriptif, dan overlay peta tematik. Hasil dari penelitian ini adalah tingkat kesiapan pengembangan kawasan commercial strip di Surakarta Utara bagian Barat berada pada kategori cukup siap. Cukup siap berarti kawasan Surakarta Utara bagian Barat layak dikembangkan sebagai pusat aktivitas baru namun perlu dilakukan perbaikan pada beberapa aspek. Perlu perencanaan yang komprehensif baik aspek yang sudah memenuhi kriteria maupun yang belum memenuhi kriteria kesiapan agar seluruh komponen kesiapan berada pada tingkat kesiapan yang memadai. Maka dari itu, perencanaan yang perlu dilakukan yaitu mengembangkan kawasan commercial strip dengan konsep strip-center development pada area di sekitar jaringan jalan agar pemanfaatan lahan menjadi lebih efisien dan mengurangi beban perjalanan.
\end{abstract}

Kata kunci : commercial strip; kawasan perdagangan; kesiapan; pengembangan wilayah

\begin{abstract}
Based on RTRW Surakarta City 2011-2031, northwestern Surakarta is a strategic area in terms of economic growth. Commercial corridors at northwestern Surakarta are planned through Adi Sumarmo, Mangunsarkoro and Pierre Tendean street corridors. Commercial strip is a linear development of stores and service located along major roadways and extending to length one block (Silberberg, 1976). Development in the northern region is needed to reduce the burden of activity that currently becomes activity centres. However, development in the northern region still needs improvement in physical and non-physical aspects such as improvement of supporting infrastructure and investment level. It is necessary to know the level of preparedness in the commercial strip area at northwestern Surakarta based on the physical and non physical aspects. This research is using deductive method in its approach. Method of data collecting used were purposive sampling, observation, and questionnaire to provide primary data while literature study was used to provide secondary data. Analytical techniques used in this research were descriptive statistical techniques and overlay thematic maps. The result of this research is the level of readiness of commercial strip area development in northwestern Surakarta was adequately ready. It means that the northwestern Surakarta was worthy of being developed as a new activity center but needs to be improved on several aspects. It needs comprehensive planning that fulfills both criteria and those that do not meet the criteria of readiness so that all components of readiness are at an adequate level of readiness. Therefore, the planning that needs to be done is to develop commercial strip area with the concept of strip-center development on the area around the road network so that the land use around it becomes more efficient and reduce travel expenses.
\end{abstract}

Keywords : commercial strip; commercial area; readiness; regional development

\section{PENDAHULUAN}

Kawasan Surakarta bagian Utara, berdasarkan RTRW Kota Surakarta tahun 2011-2031 termasuk kawasan strategis dari segi pertumbuhan ekonomi meliputi Kelurahan Banyuanyar, Nusukan, Kadipiro dan Mojosongo. Kawasan 
Surakarta Utara memiliki potensi pengembangan kawasan perdagangan dan jasa. Pengembangan kawasan perdagangan di Surakarta selatan sudah tidak memungkinkan karena ketersediaan lahan semakin terbatas. Koridor komersial (commercial strip) pada kawasan Surakarta Utara direncanakan sesuai RDTR Kota Surakarta tahun 20122032 meliputi koridor Jalan Adi Sumarmo, Mangunsarkoro dan Pierre Tendean. Koridor komersial (commercial strip) adalah pengembangan kawasan perdagangan di sekitar jaringan jalan dengan memanfaatkan faktor aksesibilitas sebagai daya tarik utama. Penataan koridor Adi Sumarmo termasuk dalam rencana pengembangan Solo Utara menjadi $\mathrm{CBD}$ atau daerah pusat aktivitas. Dengan mengetahui tingkat kesiapan pengembangan kawasan Utara sebagai pusat aktivitas baru, diharapkan dapat memberikan kontribusi kepada penelitian-penelitian selanjutnya sebagai rujukan konsep pengembangan wilayah perdagangan dengan konsep commercial strip

Pengembangan Solo Utara diperlukan untuk mengurangi beban aktivitas pada bagian selatan yang saat ini menjadi pusat aktivitas Kota Surakarta. Penyediaan infrastruktur penunjang di Solo Utara dinilai belum optimal dari aspek fisik dan non-fisik. Misalnya masih ditemukan jalan yang rusak, penyediaan air bersih, kemacetan dan ancaman bencana banjir tahunan. Terlebih masih banyak program pemerintah yang belum terimplementasi secara maksimal dan tingkat investasi yang masih rendah. Namun, Pemerintah Kota Surakarta telah melakukan upaya dalam rangka percepatan pengembangan kawasan Utara sebagai pusat aktivitas baru. Salah satunya dengan memberikan insentif kepada investor untuk bekerjasama dalam pengembangan Kawasan Solo Utara. Pengembangan commercial strip diharapkan dapat menunjang pengembangan wilayah Surakarta Utara sehingga terjadi pemerataan pembangunan. Berdasarkan kondisi di atas, dapat ditarik pertanyaan penelitian bagaimana tingkat kesiapan kawasan commercial strip di Surakarta Utara bagian Barat yang ditinjau dari aspek fisik dan non-fisik. Tujuan penelitian ini adalah untuk mengetahui kesiapan pengembangan kawasan commercial strip di Surakarta Utara bagian Barat yang ditinjau dari aspek fisik dan non-fisik.

\section{KAJIAN TEORI}

\subsection{Definisi Kawasan Commercial strip}

Menurut Kustiwan (2009), kawasan adalah ruang yang merupakan kesatuan geografis beserta segenap unsur terkait padanya yang batas dan sistemnya ditentukan berdasarkan aspek fungsional serta memiliki ciri tertentu/khusus. Kawasan dibagi menjadi kawasan perkotaan, kawasan perdesaan, dan kawasan khusus. Kawasan pusat perdagangan umumnya terdapat pada kawasan perkotaan. Terdapat beberapa klasifikasi kawasan perdagangan berdasarkan lokasi. Menurut Berry (1970), kawasan perdagangan berkembang di area sub-urban yang belum terencana berupa area retail di sepanjang koridor jalan. Salah satu model pengembangan kawasan perdagangan yakni perdagangan berderet mengikuti pola jalan atau disebut koridor komersial. Menurut Horwitz (1985), koridor komersial (commercial strip) adalah kawasan perdagangan yang berbentuk memanjang mengikuti pola jaringan jalan, bangunan berbentuk kotak (big-box building), terdapat banyak reklame komersial dan tergantung pada penggunaan kendaraan bermotor. Commercial strip memiliki batasan wilayah seluas satu blok dari jalan utama.

\subsection{Karakteristik Kawasan Commercial strip}

Menurut Moldoff (2004), commercial strip memiliki ciri area perdagangan berbentuk linear yang berfungsi untuk retail bisnis terletak pada jaringan jalan utama, mempunyai bangunan pertokoan berderet dengan parkir yang berada di sepanjang jalan, memiliki volume lalu lintas yang tinggi, penanda (signage) dan sangat berorientasi pada penggunaan kendaraan bermotor sebagai sirkulasi. Menurut Trent (1998), commercial strip memiliki elemen pembentuk pertokoan, infrastruktur publik, lalu lintas kendaraan tinggi, signage komersial (reklame) sebagai ciri khas kawasan dan kondisi alam. Selain itu, Oregon Department of Land Conservation and Development (2000) menyatakan bahwa commercial strip adalah lokasi dengan karakteristik automobile. Automobile yang dimaksud adalah kawasan yang sangat bergantung pada penggunaan kendaraan dengan kata lain kawasan ini memiliki ciri pengguna kendaraan yang sangat tingi. Beberapa karakteristik commercial strip menurut Oregon Department of Land Conservation and Development (2000) antara lain pertokoan yang sejajar dengan jalan, memiliki area parkir yang di depan pertokoan. Terdapat pada jaringan jalan utama yang memiliki lalu lintas padat dan intensitas pembangunannya rendah, hanya satu atau dua lantai.

Menurut Tung dan Sasaki (2010), commercial strip merupakan bentuk linear pengembangan lokasi perdagangan dengan menggunakan keuntungan lokasi yang aksesibel. Pertokoan yang berjejer memiliki ruang parkir terbatas sehingga terdapat pula parkir yang berada di jalan. Reklame pada commercial strip terpasang di dekat jalan utama sehingga terlihat tidak teratur. Lokasi pengembangan kawasan commercial strip harus aman terhadap bencana. 
Infrastruktur kawasan juga harus ditunjang dengan keberadaan prasarana yang memadai. Kawasan perdagangan ditunjang dengan fasilitas air bersih, penerangan jalan dan sistem drainase yang baik. Fasiltias tersebut berpengaruh secara langsung terhadap kenyamanan. Drainase yang tersumbat menyebabkan gangguan lalu lintas sedangkan penerangan jalan berkontribusi terhadap keamanan pada malam hari.

Commercial strip merupakan kawasan yang memiliki karakteristik khusus dan kecenderungan mengalami perkembangan ruang menjadi pusat aktivitas. Maka dari itu, kawasan ini memiliki nilai strategis dalam tata ruang perkotaan. Menurut Oregon Transportation and Growth Management (2002), menjabarkan mengenai langkah langkah yang dapat dilakukan stakeholder untuk mengembangkan kawasan commercial strip. Rencana pembangunan kawasan komersil meliputi rencana zonasi dan rencana investasi.

Rencana zonasi berupa rencana pemanfaatan dan pengendalian lahan pada kawasan commercial strip. Rencana zonasi memiliki tingkat kedetilan yang cukup tinggi sehingga dapat menjamin kawasan commercial strip dapat berkembang secara terarah. Rencana zonasi commercial strip mengarahkan kepadatan fungsi, bentuk muka bangunan, sirkulasi kendaraan maupun pejalan kaki hingga penyediaan ruang terbuka dan permukiman berkepadatan tinggi. Rencana zonasi membantu perencana untuk mengalokasikan pembagian zonasi dalam kawasan commercial strip saling mendukung satu dengan yang lain.

Rencana investasi mengarahkan pengembangan kawasan komersial kepada potensi keuntungan bagi stakeholder. Maka dari itu, kerjasama dengan sektor swasta penting dalam hal pengembangan kawasan. Bentuk umum kerjasama pemerintah dan swasta dalam hal pembiayaan. Pembiayaan meliputi pengadaan barang dan jasa, perawatan serta pemeliharaan sarana prasarana. Untuk menarik investor untuk berinvesatsi, stakeholder melakukan langkah-langkah seperti memberikan insentif kepada investor. Beberapa insentif dilakukan pemerintah untuk menarik investor untuk melakukan pengembangan pada kawasan komersial yang potensial seperti kemudahan pemberian izin dan kesepakatan pengelolaan infrastuktur.

\subsection{Pengembangan Kawasan Commercial strip}

Pengembangan kawasan bermaksud untuk memperkecil kesenjangan pertumbuhan dan ketimpangan antar wilayah. Menurut Susilo (2000) dan Widyaningsih (2001), kajian pengembangan kawasan didekati dari aspek sektoral dan aspek spasial. Aspek sektoral menyatakan ukuran dari aktivitas (segi non-fisik) dalam mengelola sumber daya yang dimiliki. Sementara aspek spasial (segi fisik) menunjukkan dimana lokasi kegiatan sektoral dilakukan. Pengembangan kawasan commercial strip diharapkan dapat memperbaiki kondisi perekonomian masyarakat, memperbaiki penggunaan ruang publik dan memiliki nilai guna lebih. Menurut Reardon \& Dann Brunner (2011), menyatakan pengembangan kawasan commercial strip memiliki cetak biru yang spesifik sesuai dengan karakteristik penggunanya. Koridor komersil yang memiliki potensi pengembangan adalah kawasan yang memiliki karakteristik kepadatan pertokoan dengan berbagai macam fungsi, memiliki fasilitas parkir yang memadai, manajemen administrasi, dan lingkungan fisik yang nyaman.

\subsection{Variabel Penelitian}

Dalam menentukan tingkat kesiapan kawasan commercial strip, maka dibutuhkan variabel dan indikator penelitian. Variabel dan indikator penelitian untuk menentukan tingkat kesiapan diperoleh dari sintesis karakteristik kawasan commercial strip dengan konsep pengembangannya. Maka tingkat kesiapan kawasan commercial strip merupakan ukuran karakteristik kawasan commercial strip apakah sudah memenuhi atau belum memenuhi kriteria dari konsep pengembangannya. Berikut adalah tabel variabel dan indikator penelitian kesiapan kawasan commercial strip.

Tabel 1. Variabel Operasional

\begin{tabular}{|c|c|c|c|c|}
\hline $\begin{array}{c}\text { Aspek } \\
\text { Pengembangan } \\
\text { Kawasan }\end{array}$ & $\begin{array}{c}\text { Karakteristik } \\
\text { Commercial Strip }\end{array}$ & $\begin{array}{l}\text { Konsep Pengembangan } \\
\text { Commercial Strip }\end{array}$ & Variabel & Indikator \\
\hline \multirow[t]{4}{*}{ Fisik } & $\begin{array}{ll}\begin{array}{l}\text { Pusat } \\
\text { ekonomi }\end{array} & \text { kegiatan } \\
\end{array}$ & \multirow[t]{4}{*}{$\begin{array}{l}\text { Didukung kondisi } \\
\text { eksisting retail }\end{array}$} & \multirow{4}{*}{$\begin{array}{l}\text { Kelengkapan infrastruktur } \\
\text { kawasan commercial } \\
\text { strip }\end{array}$} & $\begin{array}{l}\text { Skala pelayanan pusat } \\
\text { perbelanjaan }\end{array}$ \\
\hline & Prasarana air bersih & & & $\begin{array}{l}\text { Cakupan pelayanan air } \\
\text { bersih }\end{array}$ \\
\hline & Prasarana drainase & & & Tingkat kinerja drainase \\
\hline & Reklame pertokoan & & & Keteraturan reklame \\
\hline
\end{tabular}




\begin{tabular}{|c|c|c|c|c|}
\hline $\begin{array}{c}\text { Aspek } \\
\text { Pengembangan }\end{array}$ & $\begin{array}{c}\text { Karakteristik } \\
\text { Commercial Strip }\end{array}$ & $\begin{array}{c}\text { Konsep Pengembangan } \\
\text { Commercial Strip }\end{array}$ & Variabel & Indikator \\
\hline & Area parkir & Ketersediaan parkir & & Kapasitas parkir \\
\hline & Pola pertokoan linear & Kepadatan pertokoan & \multirow[t]{2}{*}{$\begin{array}{l}\text { Pola tata guna lahan } \\
\text { commercial strip }\end{array}$} & $\begin{array}{l}\text { Kepadatan linear } \\
\text { pertokoan }\end{array}$ \\
\hline & Fungsi mixed use & Keberagaman fungsi & & $\begin{array}{ll}\text { Keberagaman guna } \\
\text { lahan }\end{array}$ \\
\hline & $\begin{array}{l}\text { Volume lalu lintas } \\
\text { tinggi }\end{array}$ & Aksesibilitas yang stabil & Aksesibilitas & Pelayanan Ialu lintas \\
\hline & $\begin{array}{ll}\text { Aman } & \text { terhadap } \\
\text { bencana } & \\
\end{array}$ & \multirow[t]{2}{*}{$\begin{array}{l}\text { Didukung lingkungan fisik } \\
\text { yang baik }\end{array}$} & \multirow[t]{2}{*}{ Daya dukung lingkungan } & Tingkat kebencanaan \\
\hline & $\begin{array}{l}\text { Mudah } \\
\text { dikembangkan }\end{array}$ & & & $\begin{array}{l}\text { Tingkat kemudahan } \\
\text { pengembangan }\end{array}$ \\
\hline \multirow[t]{2}{*}{ Non Fisik } & $\begin{array}{l}\text { Rencana } \\
\text { pembangunan }\end{array}$ & \multirow[t]{2}{*}{ Manajemen administratif } & Kebijakan perencanaan & $\begin{array}{l}\text { Efektivitas implementasi } \\
\text { rencana pembangunan }\end{array}$ \\
\hline & $\begin{array}{l}\text { Kerjasama } \\
\text { pembangunan }\end{array}$ & & Kerjasama pembangunan & $\begin{array}{l}\text { Kelayakan kerjasama } \\
\text { pembangunan }\end{array}$ \\
\hline
\end{tabular}

Sumber : (Moldoff, 2004); (Trent, 1998); (Tung \& Sasaki, 2010); (ODLC, 2000); (Reardon \& Dan Brunner, 2011)

\section{METODE PENELITIAN}

\subsection{Pendekatan dan Jenis Penelitian}

Pendekatan penelitian secara deduktif teori digunakan sebagai dasar penelitian untuk mengukur kesiapan kawasan commercial strip. Pendekatan penelitian ini berdasarkan adanya fenomena perubahan guna lahan menjadi fungsi komersil. Jenis penelitian ini adalah kuantitatif karena pengukuran tingkat kesiapan commercial strip memiliki unsur fisik keruangan yang dapat diukur secara kuantitatif. Penelitian tingkat kesiapan kawasan commercial strip di Surakarta Utara bagian Barat memiliki delineasi sejauh satu blok pertama dari jaringan jalan utama sesuai dengan pernyatan Horwitz (1985) yang mana kawasan commercial strip memiliki luasan satu blok dari jalan utama. Dalam penelitian ini terdapat perbedaan bobot pada variabel tertentu karena merupakan aspek penting untuk pengembangan kawasan commercial strip.

Teknik pengumpulan data yang digunakan pada penelitian ini menggunakan teknik studi literatur, observasi dan kuesioner. Teknik studi literatur adalah data sekunder dari instansi pemerintahan, website dan peta digital berbentuk shapefile. Teknik observasi pada penelitian ini melakukan peninjauan lapangan seperti pencatatan lalu lintas dan pemetaan. Kuesioner dilakukan dengan memberikan kuesioner kepada narasumber untuk diisi kuesioner tersebut sudah tertera kebutuhan data yang diperlukan.

Teknik analisis dalam penelitian ini dibagi menjadi 2 tahap. Tahap pertama analisis secara teknik deskriptif kuantitatif dan GIS kemudian hasil analisis diberi skor yang setiap aspek memiliki bobot tertentu. Penentuan bobot pada variabel berdasarkan banyaknya literatur yang menyatakan urgensi variabel tersebut pada konteks penelitian. Setiap indikator dianalisis menggunakan teknik analisis yang relevan. Teknik analisis deskriptif kuantitatif pada penelitian ini menggunakan pedoman analisis secara perhitungan aritmatik. Sedangkan analisis GIS menggunakan teknik overlay dan buffer. Overlay adalah teknik tumpah tindih peta yang memiliki karakteristik berbeda sehingga menghasilkan karakteristik baru. Teknik buffer adalah teknik mengukur jangkauan objek dalam rentang jarak tertentu. Berikut bobot pada setiap variabel penelitian.

Tabel 2. Bobot Variabel Penelitian

\begin{tabular}{|l|l|l|l|}
\hline \multicolumn{1}{|c|}{ Variabel } & \multicolumn{1}{|c|}{ Indikator } & Bobot & Total \\
\hline \multirow{4}{*}{$\begin{array}{l}\text { Kelengkapan infrastruktur kawasan } \\
\text { commercial strip }\end{array}$} & Skala pelayanan pusat perbelanjaan & 0,28 & 1,4 \\
\cline { 2 - 4 } & Cakupan pelayanan air bersih & 0,28 & \\
\cline { 2 - 4 } & Tingkat kinerja drainase & 0,28 & \\
\cline { 2 - 4 } & Keteraturan reklame & 0,28 & \\
\cline { 2 - 4 } & Kapasitas parkir & 0,28 & \\
\hline Pola tata guna lahan commercial strip & Kepadatan linear pertokoan & 0,24 & 0,48 \\
\cline { 2 - 3 } & Keberagaman guna lahan & 0,24 & \\
\hline Aksesibilitas & Pelayanan lalu lintas & 0,19 & 0,19 \\
\hline
\end{tabular}




\begin{tabular}{|l|l|c|c|}
\hline \multicolumn{1}{|c|}{ Variabel } & \multicolumn{1}{|c|}{ Indikator } & Bobot & Total \\
\hline Daya dukung lingkungan & Tingkat kebencanaan & 0,05 & 0,10 \\
\cline { 2 - 3 } & Tingkat kemudahan pengembangan & 0,05 & \\
\hline Kebijakan perencanaan & Efektivitas implementasi rencana pembangunan & 0,15 & 0,15 \\
\hline Kerjasama pembangunan & Kelayakan kerjasama pembangunan & 0,09 & 0,09 \\
\hline TOTAL SKOR & & 2,4 \\
\hline
\end{tabular}

Sumber : Pamungkas, Muhammad Rizal Fernandita, dkk., 2017

Setelah diketahui nilai tertinggi skor total kemudian membagi menjadi 3 kelas kesiapan yakni siap dikembangkan, cukup siap dikembangkan dan tidak siap dikembangkan. Penelitian ini membagi menjadi 3 kelas kesiapan karena penelitian mengenai tingkat kesiapan memiliki kemungkinan dimana terdapat suatu kondisi sedang. Sedang berarti tidak dapat dikatakan siap seluruhnya namun juga tidak bisa dikatakan tidak siap sama sekali. Berikut merupakan tabel tingkat kesiapan pengembangan kawasan commercial strip Surakarta Utara bagian Barat.

Tabel 3. Tingkat Kesiapan Pengembangan Commercial Strip

\begin{tabular}{|l|l|}
\hline \multicolumn{1}{|c|}{ Skor Interval } & \multicolumn{1}{c|}{ Tingkat Kesiapan } \\
\hline $0-0,8$ & Tidak siap dikembangkan sebagai kawasan commercial strip \\
\hline $0,9-1,6$ & $\begin{array}{l}\text { Cukup siap dikembangkan sebagai kawasan commercial strip, layak dikembangkan dengan syarat } \\
\text { tertentu }\end{array}$ \\
\hline $1,7-2,4$ & Siap dikembangkan sebagai kawasan commercial strip \\
\hline
\end{tabular}

Sumber : Pamungkas, Muhammad Rizal Fernandita, dkk., 2017

Teknik pembahasan pada penelitian ini menggunakan metode deskriptif kualitatif menggunakan sudut pandang teori dan penulis. Sudut pandang teori dibutuhkan sebagai dasar untuk menjelaskan fenomena dari analisis, sedangkan sudut pandang penulis berguna memberi tambahan informasi terkait langkah untuk menyikapi kondisi tersebut. Pembahasan membuat hasil analisis menjadi lebih informatif sehingga dapat menjawab pertanyaan penelitian secara spesifik. Berikut skor interval tingkat kesiapan pengembangan kawasan commercial strip Surakarta Utara bagian Barat.

\section{HASIL DAN PEMBAHASAN}

\subsection{Aspek Fisik}

Kawasan commercial strip Surakarta Utara bagian Barat memiliki pusat perbelanjaan dengan hirarki lengkap. Sebagai kawasan perdagangan yang memiliki pola memanjang mengikuti pola jaringan jalan, commercial strip harus memiliki pusat kegiatan yang dapat melayani penduduk dalam skala pelayanan yang bervariasi. Corner stores sebagai pusat perbelanjaan dengan hirarki terendah melayani skala lingkungan yang berupa toko eceran. Selanjutnya, neighborhood center melayani skala lokal berupa minimarket dan toko grosir. Hirarki ketiga city center melayani skala kota. City centers berupa supermarket. Hirarki tertinggi yakni regional center melayani kebutuhan penduduk skala regional berupa pasar regional. Pusat perbelanjaan pada commercial strip Surakarta harus dapat saling menunjang. Artinya, pusat perbelanjaan yang berada pada hirarki di bawah, harus bisa menunjang pusat perbelanjaan yang memiliki hirarki di atasnya. Penentuan lokasi pusat perbelanjaan harus sesuai dengan tingkat aksesibilitasnya, pusat perbelanjaan berskala regional tentu harus berada pada jaringan jalan utama, sedangkan pusat perbelanjaan berskala lokal harus berada di dekat permukiman agar masyarakat tidak perlu mengakses pusat perbelanjaan regional ketika telah mampu tercukupi oleh pusat perbelanjaan skala lokal.

Kondisi cakupan pelayanan air bersih belum dapat memenuhi kebutuhan air. Dengan jumlah kapasitas tersebut, PDAM perlu meningkatkan jumlah cakupan air bersih untuk mencukupi kebutuhan air bersih pada kawasan commercial strip. PDAM Kota Surakarta baru mampu melayani kebutuhan air masyarakat sebesar $55 \%$ dari target $80 \%$. Akibatnya pada saat jam puncak sebagian kawasan selatan dan Utara, tekanan airnya sangat rendah bahkan beberapa kawasan tidak dapat menerima air. Berdasarkan perbandingan kebutuhan total (16,7 It/dt) dengan kapasitas produksi (14,03 lt/dt) maka perlu meningkatkan kapasitas produksi agar kebutuhan air bersih kawasan commercial strip. Terbatasnya kapasitas produksi air bersih perlu diatasi dengan beberapa pendekatan. Pada umumnya rendahnya kapasitas produksi sumber air bersih akibat sedikitnya produksi sumber air dalam menyuplai air bersih dan kebocoran saat distribusi. Maka dari itu, perlu upaya peningkatan kapasitas produksi dengan mengoptimalisasi sumur dalam, mengurangi tingkat kebocoran dengan perbaikan jaringan distribusi perpipaan dan pembuatan sumur dalam baru yang memiliki kapasitas cukup untuk menyuplai kebutuhan air bersih kawasan commercial strip. 
Prasarana drainase masih dapat menampung debit total. Debit buangan pada sektor komersil pada saat ini masih dapat ditampung namun pada masa mendatang perlu dilakukan perencanaan sistem drainase perkotaan yang memiliki kapasitas debit lebih besar. Peningkatan aktivitas akibat pengembangan kawasan menuntut kualitas prasarana juga ditingkatkan. Sistem drainase pada kawasan commercial strip Surakarta Utara bagian Barat berjenis tertutup sehingga aliran air tidak terhambat oleh sampah yang mungkin masuk ke dalam saluran drainase. Sistem perencanaan drainase perkotaan harus terintegrasi antar saluran. Saluran saluran tersier hingga saluran primer (daerah aliran sungai) harus dalam kondisi baik. Saat ini pemerintah Kota Surakarta telah mengerjakan proyek perbaikan sistem drainase pada kawasan Utara meliputi Jalan Adi Sumarmo, Pierre Tendean hingga Kali Pepe. Selain itu Pemerintah Kota Surakarta juga membenahi talut pada Kali Gajah Puth sebagai drainase primer kawasan Utara. Perbaikan drainase dilakukan secara bertahap karena keterbatasan anggaran. Untuk itu perlu dilakukan pemeliharaan dan perawatan saluran drainase pada kawasan commercial strip untuk menjaga kinerja saluran drainase.

Kondisi reklame masih memerlukan penataan. Berdasarkan kondisi penataan reklame pada kawasan commercial strip Surakarta Utara bagian Barat memerlukan penataan tata letak reklame. Reklame adalah penanda suatu kawasan dengan ciri utama sebagai kawasan perdagangan, maka dari itu penataan reklame menjadi penting dalam pengembangan kawasan perdagangan. Penentuan lokasi penempatan reklame sangat berpengaruh untuk mengurangi pencemaran visual yang dihasilkan pada pemasangan reklame yang berukuran cukup besar. Reklame yang berukuran cukup besar dapat menganggu penglihatan pengendara saat melintasi kawasan sehingga sangat penting bagi penataan reklame pada kawasan commercial strip.

Kapasitas parkir kawasan commercial strip Surakarta Utara bagian Barat secara umum dapat memenuhi kriteria kesiapan. Parkir on street memungkinkan dilakukan pada koridor Adi Sumarmo dan Mangunsarkoro. Nilai LOS pada koridor Pierre Tendean yang menunjukkan kecenderungan tidak stabil tidak disarankan untuk sistem on street. Sistem parkir off street dapat dilakukan apabila nilai LOS berada di bawah 0,69. Preferensi pengunjung pertokoan lebih menginginkan lokasi parkir yang tidak jauh dari toko namun penyediaan lahan parkir tidak memungkinkan karena apabila menggunakan sistem on street berpotensi mengurangi kinerja jalan. Maka dari itu, perlu penanganan masalah parkir pada commercial strip yang dapat mengakomodir kebutuhan parkir pengunjung namun tanpa mengurangi kinerja jalan. Konsep shared parking dapat diaplikasikan pada lokasi yang memiliki pola permintaan parkir yang berbeda. Misalnya permintaan parkir perkantoran berada pada jam puncak saat hari kerja sementara permintaan untuk hiburan dan rekreasi pada malam hari/akhir pekan. Namun semua dilakukan pada satu lahan parkir. Area shared parking berada di lokasi atau di luar kawasan, namun harus diperhatikan jarak lokasi parkir cukup dekat dengan kawasan commercial strip Surakarta Utara bagian Barat.

Rendahnya angka kepadatan bangunan komersial cukup beralasan karena memang selama ini pengembangan di wilayah Surakarta Utara masih minim. Selama ini pembangunan masih terpaku pada Kawasan Surakarta selatan, namun belakangan Pemerintah Kota Surakarta sudah mulai memperhatikan kawasan Utara sebagai wilayah potensial pengembangan aktivitas baru. Hal ini ditandai dengan masifnya pembangunan infrastruktur seperti perbaikan jalan, drainase serta pertokoan komersil di sepanjang Jalan Adi Sumarmo, Mangunsarkoro dan Pierre Tendean. Pembangunan Surakarta Utara diperlukan untuk mengurangi beban pembangunan dan pemerataan pembangunan di Kota Surakarta. Maka dari itu perlu melakukan penambahan sarana perdagangan agar kepadatan bangunan komersil dapat memenuhi kriteria kesiapan. Strip-center development perlu dipertimbangkan dalam pengembangan kawasan commercial strip yakni dengan memusatkan aktivitas perdagangan pada area commercial strip sehingga penambahan fasilitas perdagangan sesuai dengan kebutuhan kawasan commercial strip. Pemusatan aktivitas berarti dapat menghemat penggunaan sarana prasarana, bahan bakar dan efisiensi penggunaan lahan.

Keberagaman penggunaan lahan pada kawasan commercial strip Surakarta Utara bagian Barat telah memenuhi kriteria kesiapan. Seluruh koridor memiliki lebih dari 3 campuran guna lahan. Namun campuran guna lahan tersebut belum saling mendukung satu dengan yang lain. Maka dari itu, konsep mixed-use development dapat diterapkan pada kawasan commercial strip. Konsep ini dapat mengurangi beban perjalanan karena banyak aktivitas yang dikonsentrasikan pada satu lokasi. Tidak hanya campuran guna lahan namun juga campuran fungsi bangunan. Dengan konsep tersebut, masyarakat tidak perlu menggunakan kendaraan pribadi untuk mengakses kawasan commercial strip. Misalnya suatu lokasi memiliki fungsi utama sebagai kawasan perdagangan dapat ditunjang dengan hunian komersil seperti hotel dan pelayanan publik. Masyarakat memiliki banyak pilihan untuk mengakses kebutuhannya dalam satu lokasi yang saling berdekatan. Tidak hanya campuran guna lahan yang terintegrasi namun juga variasi fungsi bangunan. Satu bangunan memungkinkan untuk digunakan sebagai hunian sekaligus toko sehingga penggunaan lahan 
menjadi lebih efisien. Dengan bertambahnya fungsi bangunan, tentu saja meningkatkan rasio lantai bangunan sehingga mengurangi lahan dengan intensitas pemanfaatan rendah.

Tingkat pelayanan lalu lintas pada kawasan commercial strip memenuhi kriteria kesiapan yang menggambarkan kondisi lalu lintas yang stabil. Peningkatan intensitas aktivitas pada kawasan commercial strip memberi dampak penurunan kinerja jalan yang disebabkan bertambahnya volume lalu lintas sementara kapasitas jalan cenderung stagnan. Penambahan volume lalu lintas merupakan fenomena yang umum akibat peningkatan aktivitas perdagangan pada suatu wilayah. Untuk menghindari terjadinya kemacetan pada kawasan commercial strip Surakarta Utara bagian Barat, perlu dilakukan manajemen transportasi berbasis Transport Demand Management (TDM). Transport Demand Management (TDM) berfungsi mengendalikan volume pergerakan sehingga pergerakan dapat diturunkan seminimal mungkin dan meningkatkan penggunaan angkutan umum. Artinya, TDM tidak melarang penggunaan kendaaraan pribadi tetapi membatasi penggunaannya. Pada kawasan commercial strip Surakarta Utara bagian Barat memiliki karakteristik pergerakan kendaraan berat dengan volume lalu lintas yang cukup besar. Hal ini apabila dibiarkan akan merusak kondisi jalan. Selain kendaraan berat juga dilalui oleh kendaraan pribadi yang cukup padat pada saat jam puncak sehingga menyebabkan kemacetan di simpang Tirtonadi dan simpang Joglo.

Kawasan commercial strip Surakarta Utara bagian Barat memiliki tingkat resiko bencana sedang. Bencana alam banjir terjadi memiliki rentang tahunan pada kawasan commercial strip Surakarta Utara bagian Barat. Terjadinya banjir di commercial strip akibat banjir kiriman dari Kabupaten Boyolali. Secara topografi, Kota Surakarta di kelilingi oleh dataran tinggi sehingga Kota Surakarta merupakan daerah rawan banjir. Tingginya volume air limpasan dari dataran tinggi sekitarnya, otomatis akan menuju Kota Surakarta. Maka dari itu, perbaikan tidak hanya pada infrastruktur seperti normalisasi sungai dan perbaikan pintu air juga pelatihan pada masyarakat akan pentingnya siap siaga bencana khususnya pada penduduk di sekitar bantaran. Dalam konteks pengembangan wilayah, faktor kebencanaan menjadi aspek yang perlu diperhatikan. Terjadinya bencana dapat mengurangi kenyamanan penduduk sekitar. Untuk itu perlu adanya manajemen resiko bencana pada kawasan commercial strip Surakarta Utara bagian Barat. Pengendalian resiko bencana pada kawasan commercial strip yang paling realistis adalah dengan mengurangi dampak bencana dan meningkatkan kapasitas penanggulangan. Teknik pengendalian resiko bencana melalui pengurangan kemungkinan bencana dan menurunkan tingkat kerentanan dinilai cukup sulit dilakukan karena menyangkut kondisi alam.

Faktor lingkungan fisik memberi dampak pada kelanjutan pengembangan commercial strip. Dukungan faktor lingkungan fisik seperti bentuk muka bumi dapat mempengaruhi kemudahan pengembangan kawasan commercial strip. Kawasan commercial strip Surakarta Utara bagian Barat layak dikembangkan sebagai pusat aktivitas baru. Pengembangan kawasan commercial strip Surakarta Utara bagian Barat hendaknya memperhatikan daya dukung lingkungannya. Dengan memperhatikan daya dukung lingkungannya, pembangunan commercial strip mampu menjamin keberlanjutan dan kelestarian kehidupan masyarakat. Sebelum dilakukan pengembangan kawasan commercial strip hendaknya memperhatikan rencana tata ruang dan kajian lingkungan hidup agar pengembangan kawasan commercial strip dapat berkontribusi sesuai perannya sebagai pusat aktivitas di Surakarta Utara.

\subsection{Aspek Non Fisik}

Efektivitas implementasi rencana pembangunan sudah optimal. Rencana pembangunan kawasan Utara telah disusun pada Rencana Pembangunan Jangka Menengah Daerah (RPJMD) Kota Surakarta tahun 2016-2021. Untuk kawasan Utara fokus pada pengembangan sektor perdagangan dan jasa. Rencana pembangunan yang telah tercantum pada RPJMD sedang digarap oleh Pemerintah Kota Surakarta. Rencana pembangunan seperti pembangunan Jembatan Tirtonadi dan penyusunan RTBL Adi Sumarmo merupakan rencana prioritas pembangunan Kota Surakarta untuk kawasan Utara. Pembangunan Jembatan Tirtonadi dalam rangka peningkatan aksesibilitas menuju kawasan Nusukan. Jembatan ini diharapkan mampu mengurai kemacetan pada jam-jam sibuk. Rencana pembangunan Jembatan Tirtonadi telah direncanakan pada tahun 2016 namun baru bisa dilakukan pada tahun 2017 karena terhambat masalah pembebasan lahan penyusunan RTBL diharapkan dapat memicu peningkatan aktivitas bisnis Dengan adanya RTBL, pengembagan kawasan menjadi lebih terarah dan terukur. Implementasi seluruh rencana pembangunan kawasan commercial strip hendaknya sejalan dengan tingkat partisipasi masyarakat. Masyarakat harus dilibatkan dalam pengembangan kawasan karena masyarakat merupakan objek yang menggunakan dan memanfaatkan ruang commercial strip. Dengan perencanaan yang bersifat partisipatif, pemerintah dapat mengetahui kebutuhan kawasan yang nyata diperlukan oleh masyarakat. 
Kerjasama pengembangan kawasan belum optimal. Investasi Surakarta Utara dinilai masih kurang dalam hal tingkat ketertarikan investor. Rendahnya tingkat ketertarikan investor disebabkan masih banyaknya permasalahan yang ada di Surakarta Utara. Adanya permasalahan seperti kondisi jalan yang rusak, kemacetan dan masih sedikitnya pembangunan membuat investor cenderung memilih kawasan lain untuk menanamkan modal. Masih rendahnya tingkat ketertarikan investor dalam menanamkan modal di kawasan commercial strip Surakarta Utara menjadi kendala pembangunan pada kawasan ini. Iklim investasi Surakarta Utara pada tahun 2017 masih rendah namun mulai mengalami peningkatan seiring pembangunan kawasan Utara. Investasi Surakarta Utara dinilai masih kurang dalam hal tingkat ketertarikan investor. Dengan minimnya investor, mustahil pembangunan Kawasan Surakarta Utara segera dilaksanakan. Untuk itu, perlu rencana investasi yang diharapkan mampu membantu pembiayaan pembangunan khususnya pada sektor infrastruktur. Dana APBD tidak mencukupi untuk belanja barang dan jasa. Keterbatasan dana harus ditutupi dengan mencari sumber dana lain untuk pembangunan. Belanja barang pada sektor infrastruktur sangatlah besar maka perlu dilakukan kerjasama dengan swasta dalam pembiayaan infrastruktur. Kerjasama di bidang infrastruktur belum banyak dilakukan oleh Pemerintah Kota Surakarta. Konsep Kerjasama Pemerintah dan Swasta (KPS) dinilai dapat membantu pembiayaan pada sektor infrastruktur. Dengan adanya kerjasama pemerintah dengan swasta, sektor pembiayaan infrastruktur dapat dialihkan kepada swasta maka pemerintah dapat menghemat anggaran dan berguna sebagai percepatan pembangunan fisik kawasan commercial strip.

\subsection{Tingkat Kesiapan Pengembangan Kawasan Commercial strip}

Tingkat kesiapan kawasan commercial strip Surakarta Utara bagian Barat termasuk dalam kategori cukup siap (skor=1,47). Cukup siap berarti pengembangan kawasan commercial strip Surakarta Utara bagian Barat bisa dilakukan namun perlu perbaikan pada beberapa aspek karena masih terdapat aspek yang tidak memenuhi kriteria kesiapan. Aspek-aspek yang memenuhi kriteria kesiapan antara lain skala pelayanan pusat perbelanjaan, kinerja drainase, kapasitas ruang parkir, campuran guna lahan, pelayanan lalu lintas, kemudahan pengembangan dan efektivitas rencana pembangunan. Sedangkan aspek yang belum memenuhi kriteria kesiapan yakni cakupan pelayanan air bersih, penataan reklame, kepadatan bangunan komersil, tingkat kebencanaan dan kerjasama pengembangan kawasan. Berikut tabel hasil tingkat kesiapan kawasan commercial strip Surakarta Utara bagian Barat.

Tabel 4. Tingkat Kesiapan Pengembangan Kawasan Commercial strip

\begin{tabular}{|c|c|c|c|c|c|c|}
\hline Aspek & Variabel & Indikator & Hasil & Bobot & Skor & Total \\
\hline \multirow[t]{10}{*}{ Fisik } & \multirow{5}{*}{$\begin{array}{l}\text { Kelengkapan } \\
\text { infrastruktur } \\
\text { commercial strip }\end{array}$} & $\begin{array}{l}\text { Skala pelayanan pusat } \\
\text { perbelanjaan }\end{array}$ & $\begin{array}{l}\text { Kawasan commercial strip memiliki } \\
\text { seluruh hirarki pusat perbelanjaan }\end{array}$ & 0,28 & 1 & 0,28 \\
\hline & & $\begin{array}{l}\text { Cakupan pelayanan air } \\
\text { bersih }\end{array}$ & $\begin{array}{l}\text { Kapasitas produksi masih belum dapat } \\
\text { memenuhi kebutuhan air bersih }\end{array}$ & 0,28 & 0 & 0 \\
\hline & & Tingkat kinerja drainase & Debit saluran > debit maksimal & 0,28 & 1 & 0,28 \\
\hline & & $\begin{array}{l}\text { keteraturan penataan } \\
\text { reklame }\end{array}$ & $\begin{array}{l}\text { jarak bebas antara reklame }<150 \text { meter. } \\
\text { Terjadi penumpukan reklame pada titik } \\
\text { tertentu. (tidak memenuhi kriteria) }\end{array}$ & 0,28 & 0 & 0 \\
\hline & & kapasitas fasilitas parkir & $\begin{array}{l}\text { Standar minimal ruang parkir pada pusat } \\
\text { perbelanjaan masih dapat menampung } \\
\text { jumlah kendaraan pada peak hour. } \\
\text { (memenuhi kriteria) }\end{array}$ & 0,28 & 1 & 0,28 \\
\hline & \multirow[t]{2}{*}{$\begin{array}{l}\text { Tata guna lahan } \\
\text { commercial strip }\end{array}$} & $\begin{array}{l}\text { kepadatan bangunan } \\
\text { komersial disekitar jalan }\end{array}$ & $\begin{array}{l}\text { seluruh koridor memiliki kepadatan } \\
\text { bangunan komersial }<75 \% \text {. (tidak } \\
\text { memenuhi kriteria) }\end{array}$ & 0,24 & 0 & 0 \\
\hline & & $\begin{array}{l}\text { tingkat keberagaman guna } \\
\text { lahan commercial strip }\end{array}$ & $\begin{array}{l}\text { Seluruh koridor memiliki jumlah } \\
\text { campuran guna lahan kawasan } \\
\text { commercial strip > } 3 \text {. }\end{array}$ & 0,24 & 1 & 0,24 \\
\hline & $\begin{array}{l}\text { Kelancaran } \\
\text { sirkulasi }\end{array}$ & $\begin{array}{l}\text { Tingkat pelayanan lalu } \\
\text { lintas }\end{array}$ & $\begin{array}{l}\text { Nilai LOS dalam kategori LOS C. } \\
\text { (Memenuhi kriteria) }\end{array}$ & 0,19 & 1 & 0,19 \\
\hline & \multirow[t]{2}{*}{ Fisik Lingkungan } & $\begin{array}{l}\text { Tingkat keamanan } \\
\text { terhadap bencana }\end{array}$ & $\begin{array}{l}\text { Nilai resiko bencana }=0,38 \text {. Tingkat } \\
\text { Resiko Sedang (tidak memenuhi kriteria) }\end{array}$ & 0,05 & 0 & 0 \\
\hline & & $\begin{array}{l}\text { Tingkat kemudahan } \\
\text { pengembangan }\end{array}$ & $\begin{array}{l}\text { Nilai total skor SKL } \geq 110 \text {. Cocok } \\
\text { dikembangkan sebagai kawasan } \\
\text { budidaya. (memenuhi kriteria) }\end{array}$ & 0,05 & 1 & 0,05 \\
\hline $\begin{array}{l}\text { Non- } \\
\text { Fisik }\end{array}$ & $\begin{array}{l}\text { Kebijakan } \\
\text { perencanaan }\end{array}$ & $\begin{array}{l}\text { Efektivitas implementasi } \\
\text { rencana pengembangan } \\
\text { kawasan }\end{array}$ & $\begin{array}{l}\text { Efektivitas rencana pengembangan } \\
\text { kawasan telah memenuhi kriteria } \\
\text { kesiapan }\end{array}$ & 0,15 & 1 & 0,15 \\
\hline
\end{tabular}




\begin{tabular}{|c|c|c|c|c|c|c|}
\hline Aspek & Variabel & Indikator & Hasil & Bobot & Skor & Total \\
\hline & $\begin{array}{l}\text { Kerjasama } \\
\text { pembangunan }\end{array}$ & $\begin{array}{l}\text { Kelayakan kerjasama } \\
\text { pengembangan proyek }\end{array}$ & $\begin{array}{l}\text { Tingkat kerjasama pengembangan } \\
\text { kawasan commercial strip masih rendah }\end{array}$ & 0,09 & 0 & 0 \\
\hline \multicolumn{6}{|c|}{ Skor Total } & 1,47 \\
\hline
\end{tabular}

Sumber : Pamungkas, Muhammad Rizal Fernandita, dkk., 2017

Berdasarkan tabel di atas, beberapa aspek belum memenuhi kriteria kesiapan. Hal ini menghambat pengembangan kawasan commercial strip Surakarta Utara bagian Barat. Maka dari itu, perlu perbaikan baik aspek yang sudah memenuhi kriteria maupun yang belum memenuhi kriteria kesiapan agar seluruh komponen kesiapan berada pada tingkat kesiapan yang memadai. Kondisi Kawasan Solo Utara masih memiliki banyak kekurangan seperti cakupan pelayanan air bersih, kepadatan bangunan komersil, resiko bencana banjir dan lain lain. Namun, dalam rangka pemerataan pembangunan di Kota Surakarta, pengembangan kawasan commercial strip sebagai pusat aktivitas baru mutlak diperlukan. Dengan demikian, perlu perencanaan yang komprehensif baik dari aspek fisik dan non-fisik yang disesuaikan dengan kondisi eksisting di kawasan commercial strip Surakarta Utara bagian Barat.

\subsection{Konsep Strip-Center Development Commercial Strip Surakarta Utara Bagian Barat}

Pengembangan kawasan commercial strip Surakarta Utara bagian Barat diarahkan dengan konsep strip-center development. Konsep ini memungkinkan untuk melakukan pemusatan berbagai aktivitas pada kawasan commercial strip (satu blok dari jaringan jalan) secara terintegrasi baik antar penggunaan lahan maupun dengan sistem transportasi. Berikut merupakan peta konsep strip-center development commercial strip Surakarta Utara bagian Barat.

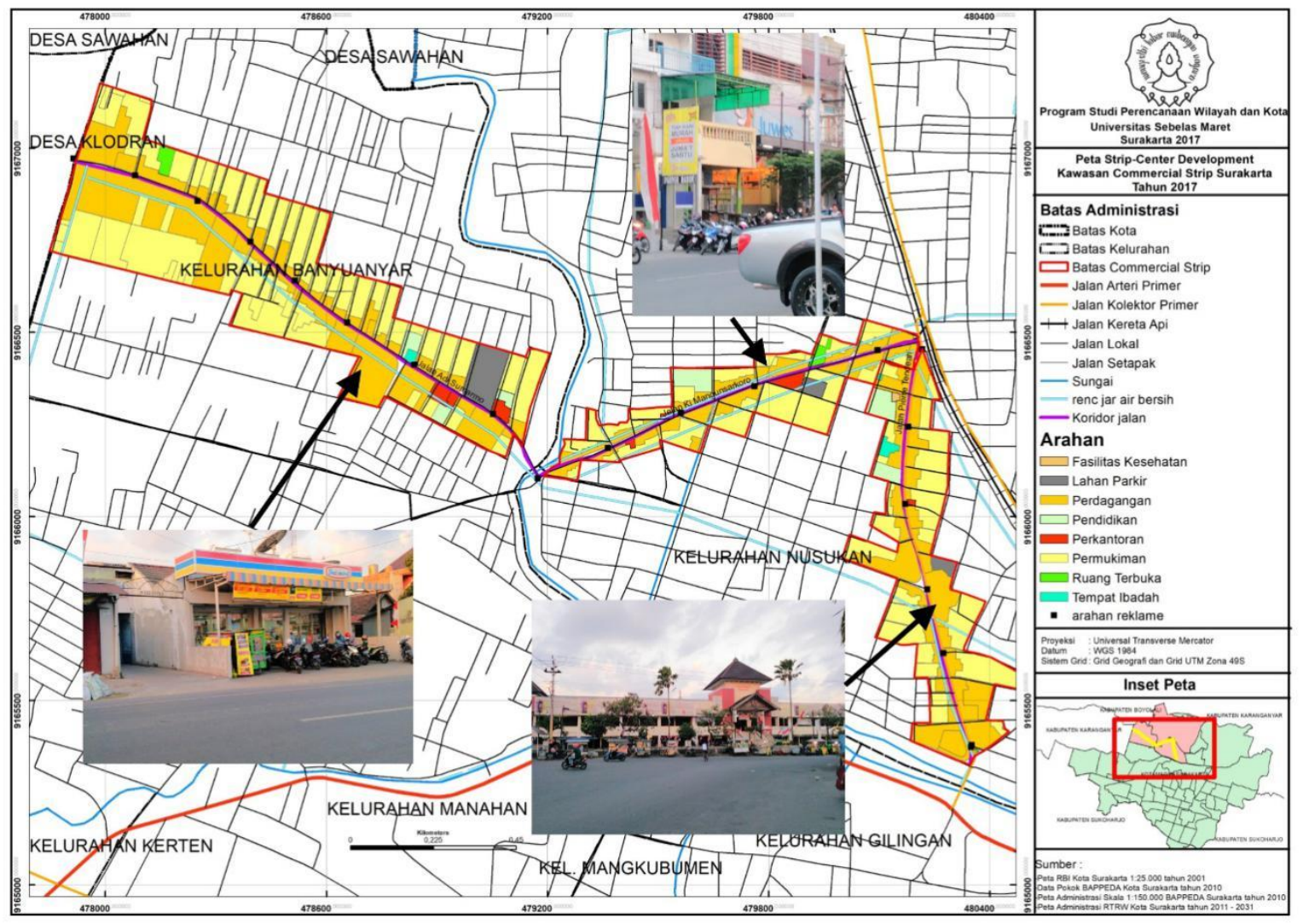

Gambar 1. Peta Strip-Center Development

\section{KESIMPULAN}

Tingkat kesiapan pengembangan kawasan commercial strip Surakarta Utara bagian Barat termasuk dalam kategori cukup siap. Cukup siap berarti pengembangan kawasan layak dilakukan di Surakarta Utara bagian Barat namun perlu perbaikan aspek kesiapan commercial strip baik yang telah memenuhi kriteria kesiapan maupun yang belum memenuhi kriteria kesiapan. Aspek yang memenuhi kriteria kesiapan yakni skala pelayanan pusat perbelanjaan, tingkat kinerja 
drainase, kapasitas parkir, keberagaman fungsi guna lahan, pelayanan lalu lintas, dan tingkat kemudahan pengembangan, dan efektivitas implementasi rencana pembangunan. Aspek yang belum memenuhi kriteria kesiapan yakni cakupan pelayanan air bersih, penataan reklame, kepadatan bangunan, tingkat investasi, keamanan terhadap bencana dan kelayakan kerjasama pembangunan. Untuk itu, perencanaan kawasan commercial strip sebagai pusat aktivitas baru harus dapat melingkupi seluruh aspek baik aspek yang telah memenuhi maupun yang belum memenuhi. Konsep strip-center development dinilai sebagai alternatif konsep pengembangan commercial strip sebagai pusat aktivitas baru. Strip-center development merupakan pengembangan commercial strip dengan memusatkan seluruh aktivitas penggunaan lahan dan segala macam sarana prasarana yang saling mendukung pada area di sekitar jalan. Dengan konsentrasi aktivitas di sekitar jaringan jalan, maka pemanfaatan lahan menjadi lebih efisien, mengurangi bangkitan perjalanan yang tidak memerlukan kendaraan, dan meningkatkan nilai ekonomi lahan.

Dalam merencanakan kawasan commercial strip sebaiknya memperhatikan seluruh aspek perencanaan baik aspek fisik maupun non-fisik. Pemerintah juga perlu menggandeng seluruh stakeholder terkait pembangunan kawasan Surakarta Utara khususnya bagian Barat. Pada dasarnya pembangunan kawasan sebagai pusat aktivitas baru memerlukan kerjasama pembangunan antara pemerintah, swasta dan masyarakat. Dengan adanya sinergi semua pihak maka pengembangan Kawasan Surakarta Utara bagian Barat akan semakin berkembang. Untuk mempersiapkan kawasan commercial strip tentunya memperhatikan aspek-aspek kriteria kesiapan kawasan commercial strip.

\section{DAFTAR PUSTAKA}

Berry, Brian. J. L. (1970). Ribbon Development in the Urban Business Pattern. Chicago: University of Chicago.

Rencana Detail Tata Ruang Kota Surakarta Tahun 2012-2032

Rencana Tata Ruang Wilayah Kota Surakarta Tahun 2011-2031

Horwitz, Richard P. (1985). The Strip : an American Place . Nebraska: University of Nebraska.

Kustiwan, Iwan. (2009). Pengantar Perencanaan Perkotaan. Bandung: ITB Bandung.

Moldoff, Ross A. (2004). Controlling Strip Development. Planning Commisioners Journal, 53.

Oregon Department of Land Conservation and Development. (2000). Containing the Commercial Strip. USA: LISC.

Oregon Transportation and Growth Management. (2002). Commercial and Mixed Use Development Code Handbook. Oregon State University.

Reardon, Patrik T. \& Dan Brunner. (2011). A Blueprint for Revitalizing Commercial Corridors . Philladelphia: LISC.

Silberbeg, Ted. (1976). A Guide for Revitalizationg of Retail District. Toronto: Members of Opportunities for Youth Project.

Susilo, K. (2000). Kebijakan Pengembangan Wilayah di Masa yang akan datang dan Implikasinya terhadap Kebutuhan Analisis dengan Memanfaatkan Sistem Informasi Geografis. Direktorat Jenderal Penataan Ruang dan Pengembangan Wilayah, Departemen Permukiman dan Pengembangan Wilayah RI.

Trent, Theodore Green. (1998). Re-Regulating The Commercial Strip. Chicago: ICF International.

Tung, Freedman \& Sasaki. (2010). Reconstructing the Commerial Strip. USA: ICF International.

Widyaningsih, Nikken Setyowati. (2001). Relevansi Preferensi Penduduk terhadap Fasilitas Kota yang Mempengaruhi Faktor Perkembangan Kota. Planit Journal, Th I/No. 2 Juli-Agustus 2001. Disertasi 